\title{
Effects of Microorganism Count and Physicochemical Properties of Tulum and Kashar Cheeses to Biogenic Amine Formation
}

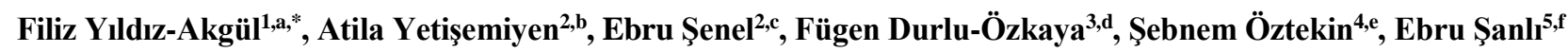 \\ ${ }^{1}$ Department of Dairy Technology, Faculty of Agriculture, Aydın Adnan Menderes University, 09100 Koçarll/Aydın, Turkey \\ ${ }^{2}$ Department of Dairy Technology, Faculty of Agriculture, Ankara University, 06110 Dlşkapi/Ankara, Turkey \\ ${ }^{3}$ Faculty of Tourism Education, Ankara Hacıbayram Veli University, 06570 Çankaya/Ankara, Turkey \\ ${ }^{4}$ Turkish Atomic Energy Authority, Nuclear Research and Education Center, 06983 Sarayköy/Ankara, Turkey \\ ${ }^{5}$ The Ministry of Agriculture and Forestry, National Food Reference Laboratory, 06800 Yenimahalle/Ankara, Turkey
}

*Corresponding author

A R T I C L E I N F O
Research Article

Received : 27/02/2018
Accepted : 18/02/2019

A B S T R A C T

In this research, biogenic amine types and quantity of Tulum and Kashar cheeses were determined. In addition, the relationship between biogenic amines and some microbiological-chemical properties of cheese samples were investigated. The contents of tryptamine, phenylethylamine, putrecine, cadaverine, histamine, tyramine of totally 40 samples (20 of each cheese) were examined. While only one sample of Tulum cheeses had no biogenic amines, different levels of biogenic amines were determined in other samples. No significant relation was confirmed between the biogenic amine quantity and total aerobic mesophilic bacteria, lactic acid bacteria, enterococci bacteria

Keywords:

Biogenic amines

Erzincan Tulum cheese

Kars Kashar cheese

Lactic acid bacteria

Hazard limit values

count, but there was a correlation between some biogenic amine contents and chemical properties which are tyrosine, lactic acid, $\mathrm{pH}$, protein and ripening coefficient. Biogenic amine levels determined in the cheeses found below hazard limit values according to what legal limit.

\section{Biyojen Amin Oluşumu Üzerine Tulum ve Kaşar Peynirlerinin Mikroorganizma İçeriği ve Fizikokimyasal Özelliklerinin Etkisi}

\begin{tabular}{l|l}
\hline M A K A L E B İ L G İ S İ & Ö Z \\
\hline Araştırma Makalesi & $\begin{array}{l}\text { Bu araştırmada, Tulum ve Kashar peynirlerinde oluşan biyojen aminlerin türü ve } \\
\text { miktarları belirlenmiştir. Ayrıca peynir örneklerinin mikroorganizma içerikleri ve bazı } \\
\text { fizikokimyasal özellikleri ile biyojen amin oluşumu arasındaki ilişki araştırılmıştır. } \\
\text { Toplam 40 peynir örneğinin (her bir peynir çeşidinden 20 adet) triptamin, feniletilamin, } \\
\text { putresin, kadaverin, histamin ve tiramin içeriği incelendi. Tulum peynirlerinde sadece } \\
\text { bir örnekte biyojen amine rastlanmazken, diğer peynir örneklerinde farklı düzeylerde } \\
\text { biyojen amin belirlenmiştir. Biyojen amin miktarı ile toplam aerobik mezofilik bakteri, } \\
\text { laktik asit bakteri, enterokok bakteri sayıları arasında önemli bir korelasyon tespit } \\
\text { edilemezken, bazı biyojen aminler ile tirozin, laktik asit, pH, protein ve olgunlaşma } \\
\text { katsayısı gibi kimyasal özellikler arasında bir korelasyon belirlenmiştir. Her iki çeşit } \\
\text { Kabul } \quad: 27 / 02 / 2018 \\
\text { peynirde de belirlenen biyojen amin miktarlarının tehlike sinır değerlerinin altında } \\
\text { olduğu bulunmuştur. }\end{array}$ \\
$\begin{array}{l}\text { Anahtar Kelimeler: } \\
\text { Biyojen amin }\end{array}$ \\
$\begin{array}{l}\text { Erzincan Tulum peyniri } \\
\text { Kars Kaşar peyniri } \\
\text { Laktik asit bakteri }\end{array}$
\end{tabular}

Tehlike sınır değerleri

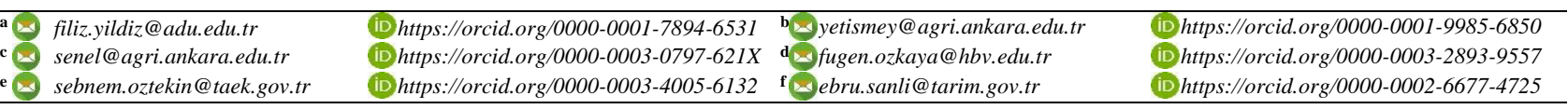




\section{Introduction}

Turkey is a rich country concerning traditional cheese varieties. Kasar (like Kashkaval), Tulum (generally it's ripened and packed in small ruminant skin or plastic material) and Lor, Dil, Otlu (with herbs), Cökelek and Mihalic are important cheeses in Turkey (Hayaloglu et al., 2002). Erzincan Tulum and Kars Kashar Cheeses are widespread known and consumed traditional cheese types. Tulum cheese has known with natural mouldy taste and flavour. Tulum cheese is produced from cow, sheep, goat's milk or mix of these milk and are sold after ripening in different packaging materials (eg leather, lacquer can, cloth, plastic drums) in many regions of the country (Keleş 1996; Ünsal, 1997; Tekinşen and Akar, 2017). After the milk is coagulated and whey is separated, curd is salted. The salted curd is ripened at $6-10^{\circ} \mathrm{C}$ in $85 \%$ relative in the goat skin (Tulum) for 3-6 months (Çolak et al., 2007). The sharp flavour and characteristic taste of Tulum cheese comes from the goat skin during the ripening. Most dairy plant use hygienic plastic packaging material to avoid microbial contamination rather than goat skin (Erdogan et al., 2003; Y1lmaz et al., 2005).

Another important traditional cheese of Turkey is Kars Kashar cheese. Similar cheeses are produced in Serbia, Romania and Bulgaria countries and known as "Kashkaval" (Öksüz et al., 2001; Sulejmani et al., 2014). There is not much difference from Kashkaval cheese, except the treatment of curd (teleme) in the step following the boiling. The shape of the Kars Kashar cheese resembles the Gruyere of French as a form and its taste flavor of the Emmental cheese of Switzerland (Eralp, 1961).

During the ripening of Tulum or Kashar cheese, decarboxylation of free amino acids which formed enzymatic hydrolysis of protein causes biogenic amine formation. Biogenic amines are low molecular weight organic, nitrogen compounds found in plant, animal and microbial cells (Alvarez and Moreno-Arribas, 2014). It is admitted that the presence of biogenic amine in cheese is an indicator the unsuitable production conditions and exposure to microbial contamination (Edwars and Sandine, 1981, Elsanhoty et al., 2009). It is known that a lot of bacteria like Escherichia, Enterobacter, Salmonella, Shigella, Achromobacter, Pseudomonas, Alcaligenes, Proteus, Clostridium, Perfringens, Micrococcus, Streptococcus, Lactobacillus and Leuconostoc produce biogenic amine at different levels (Edwards and Sandine, 1981; Joosten and Stadhouders, 1987; Joosten and Northolt, 1987; Joosten, 1988; Sumner et al., 1990; Joosten et al., 1995; Durlu-Özkaya et al., 1999; Marino et al., 2000; Durlu-Özkaya, 2001).

Biogenic amine contents of food are widely investigated due to the potential toxicity of these compounds. Symptoms caused by the biogenic amines are erythema, nausea, fever, vomiting, sweating, higher or lower tension, sore throat, thirst, swollen lips and spots on skin (Taylor et al., 1982; Chang et al., 1985; Joosten and Stadhouders, 1987; Chander et al., 1989; Stratton et al., 1991; Ladero et al., 2010).

Cheese is an ideal media for bacteria to synthesize the biogenic amines. However, the quantity and the type of biogenic amine depend on the cheese type, ripening period and microbial count (Joosten, 1988; Sumner et al 1990;
Stratton et al., 1991). Therefore the presence of biogenic amines in various types of cheeses has been widely investigated (Durlu-Özkaya et al., 1999; 2000; DurluÖzkaya and Tunail, 2000; Durlu-Özkaya, 2001; 2002; Karahan et al., 2001; Öner et al., 2002; Hocalar and Üren, 2002; Y1ldız et al., 2010; Şenel et al., 2012; Schirone et al., 2013; Renes et al., 2014)

However, there are a few studies on biogenic amine contents of Kars Kashar and Erzincan Tulum cheeses. The aims of this study were to determine the biogenic amine types and quantities present in these cheeses by HPLC. In addition, some microorganism count and physicochemical properties were also defined and the relationship with formation of biogenic amine was displayed.

\section{Materials and Methods}

\section{Material}

Twenty Tulum cheeses and twenty Kashar cheeses were purchased from different sale locations in the center of Erzincan and Kars provinces. Approximately $500 \mathrm{~g}$ of cheese samples were brought to the laboratory by maintaining the cold chain and analyse were carried out at Ankara University Dairy Technology Department.

\section{Methods}

Microbiological analyses: Total aerobic mesophilic bacteria (TAMB) count, lactic acid bacteria (LAB) and Enterobacteriaceae spp. were determined by using cultural counting methods (Harrigan and McCance, 1986; Halkman and Ayhan, 2000). TAMB was inoculated in Plate Count Agar (Merck) and incubated at $32-35^{\circ} \mathrm{C}$ for $48 \mathrm{~h}, \mathrm{LAB}$ was inoculated in MRS agar (Merck) and incubated at $40-42^{\circ} \mathrm{C}$ for 48 h, Enterobacteriaceae spp was inoculated in Violed Red Bile-Dextrose Agar (Merck) and incubated at $37^{\circ} \mathrm{C}$ for $24 \mathrm{~h}$.

Chemical analyses: The methods used for chemical analyses were as follows; total solids by gravimetric method (ISO5534, 2004), fat contents by Gerber method using Van - Gulik butyrometer (ISO3433, 2008), salt contents according to the method described in TSE 591 (Anonymous, 2013), titratable acidity as lactic acid \% according to Anonymous (2013). The $\mathrm{pH}$ values were measured by digital $\mathrm{pH}$ - meter with combined electrode (Mettler Toledo, Switzerland). Total nitrogen (TN), water soluble nitrogen (WSN) and non - protein nitrogen (NPN) contents of cheese samples were determined according to Gripon et al. (1975), tyrosine value according to Hull (1947) spectrophotometrically. Water activity was measured by Novasina thermoconstanter (Axair Ltd., Switzerland). Additionally protease peptone nitrogen (PPN) content was calculated based on NPN content from WSN content and ripening coefficient as the percentage of WSN in TN.

Determination of Biogenic Amines by HPLC

Extraction of the amines: Samples were prepared according to Maijola and Eerola (1993) and Durlu-Özkaya et al. (2000). Five grams of cheese were exposed to Acetonitrile/Percholoric acid (AP) solution (1:1) and 500 
$\mu$ of 1-7 diamino heptane (Sigma) as an internal standard (IS) were added into this mixture. The mixture was then agitated on a vortex mixer for 10 minutes, and centrifuged at $3000 \mathrm{rpm}$ for $10 \mathrm{~min}$. $200 \mu \mathrm{l}$ of aqueous layer was transferred into a test tube and $800 \mu$ of acetonitrile, 700 $\mu \mathrm{l}$ of bidistilled water, $200 \mu \mathrm{l}$ of sodium carbonate solution $(0.2 \mathrm{~g} / \mathrm{ml})$ and $100 \mu \mathrm{l}$ of dansyl chloride were added and mixture was agitated on a vortex mixer for 5 second followed by maintained in a water-bath at $37^{\circ} \mathrm{C}$ for $30 \mathrm{~min}$. $20 \mu \mathrm{l}$ of Na-glutaminate solution $(50 \mathrm{mg} / \mathrm{ml})$ were added, and agitated for $5 \mathrm{sec}$. Maintaining in water-bath at $37^{\circ} \mathrm{C}$ for $60 \mathrm{~min}$. again, $1 \mathrm{ml}$ of acetonitrile (ACN) was added and centrifuged at $3000 \mathrm{rpm}$ for $10 \mathrm{~min}$. $1 \mathrm{ml}$ of aqueous layer was placed into eppendorf tube.

Preparation of standard solutions of each biogenic amines mix: 20 ppm of standard solutions of each biogenic amines were prepared separately in $500 \mathrm{ml}$ of AP solution. $5 \mathrm{ml}$ of each of these standard solutions were dissolute in $20 \mathrm{ml}$ of AP solution and $500 \mu \mathrm{l}$ of IS were added.

Preparation of IS solution: 1 gram of 1-7 diamino heptane (Sigma) was dissolved in 1 liter bidistillated water.

HPLC Equipment: The chromatograms of biogenic amines were obtained according to Bütikofer et al. (1990). High Performance Liquid Chromatographic system (Hewlett Packard, model 1100, CA, US) equipped with reversed-phase Luna $\mathrm{C}_{18}$ column $(250 \times 4.6 \mathrm{~mm}$ id., $5 \mu \mathrm{m})$, and UV detector (HP-G $1314 \mathrm{~A}$ ) recording at $254 \mathrm{~nm}$ was used to detect biogenic amines. The flow rate was set to 1 $\mathrm{mL} \min ^{-1}$ while the column temperature was set as $35^{\circ} \mathrm{C}$. Injection volume was $20 \mu \mathrm{L}$. Mobile phases were prepared in two different ways. First Mobile phase consists of buffer/ethanol/acetonitrile/ $\mathrm{H}_{2} \mathrm{O}: 7.5 / 50 / 75 / 117.5 \mathrm{~mL}$ and the second mobile phase consists of buffer/ethanol/acetonitrile $/ \mathrm{H}_{2} \mathrm{O}: 0.5 / 112.5 / 112.5 / 25 \mathrm{~mL}$. The tris/acetic acid/ $\mathrm{H}_{2} \mathrm{O}: 2 / 1 / 2$ compose the buffer solution also.

\section{Statistical Analyses}

Minitab version 13.2 (Minitab, Inc., State College, PA, USA) was used for data analyses. A two-tailed t test at the 95\% confidence interval was conducted to determine differences in microorganism content and biogenic amines, and physicochemical properties and biogenic amines (Rosner 2006).

\section{Results and Discussion}

The mean, minimum and maximum counts TAMB, LAB and Enterobacteriaceae spp. of samples were illustrated in Table 1.

The high TAMB counts of Erzincan Tulum Cheese can be the result of raw milk use in the manufacture, long production time (minimum 10 days and microbial growth at this time) and not ripening in brine contrary to other cheese types. However, the TAMB counts that are determined were lower than the values determined by Kurt et al (1991), Dığrak et al. (1995) and Güven et al. (1995) $\left(2.13 \times 10^{9} \mathrm{cfu} / \mathrm{g}, 1.8 \times 10^{9} \mathrm{cfu} / \mathrm{g}, 2.4 \times 10^{6}-7.5 \times 10^{7} \mathrm{cfu} / \mathrm{g}\right)$. High lactic acid bacteria count is desired in Erzincan Tulum Cheese. Otherwise growth and activity of coliform group bacteria and especially proteolytic microorganisms can not be prevented (Kurt et al 1991). While the determined LAB counts in samples were in agreement with results found by Kurt et al. (1991) $\left(8.5 \times 10^{6} \mathrm{cfu} / \mathrm{g}\right)$, it was found lower than that of values reported by Diğrak et al. (1995) $\left(1.1 \times 10^{7} \mathrm{cfu} / \mathrm{g}\right)$. The fecal enterobacteria (FE bacteria) number was below $100 \mathrm{cfu} / \mathrm{g}$ in 18 samples of all the Tulum Cheese samples. The mean values of TAMB and LAB counts in Kars Kashar Cheese were higher but LAB counts were lower than the TAMB and LAB values reported in Kivanç (1989) respectively. FE counts were lower than $100 \mathrm{cfu} / \mathrm{g}$ in $20 \mathrm{Kashar}$ Cheese samples.

This cheese can be characterized by its high dry matter and fat content, hard to crumble structure, semi hard, homogenous texture and certain acidic taste (Kurt et al., 1991). According to Table 2, dry matter and fat contents of Tulum cheese samples were found to be high. Also water activity of samples was found to be low while the titratable acidity was high. It can be seen from the relevant table that Kashar Cheese was a ripened cheese type with high dry matter and fat content.

The mean value of total biogenic amine contents of Tulum cheese was determined as $1.9 \pm 0.37 \mathrm{mg} / 100 \mathrm{~g}$ (Table 3). Only one sample had no biogenic amines, yet the presence of tryptamine, phenylethylamine, putrecine, cadaverine, histamine and tyramine values were found as $55,60,75,85,65$ and $70 \%$, respectively. It was determined that the highest biogenic amine level was found for tyramine $(0.56 \pm 0.11 \mathrm{mg} / 100 \mathrm{~g})$ and it was followed by putrecine, cadaverine, phenylethylamine, tyriptamine and histamine, respectively. Tulum cheese sample and standard chromatograms are seen in Figure 1.

The amount of biogenic amines in Tulum Cheese was not found high and it was recognized that the detected levels were very much lower than the toxic doses for biogenic amines (for histamine $10 \mathrm{mg} / 100 \mathrm{~g}$, for tyramine $80 \mathrm{mg} / 100 \mathrm{mg}$ and for phenylethylamine $3 \mathrm{mg} / 100 \mathrm{~g}$ (Halasz et al., 1994).

It wasn't determined an important correlation between microorganism count and biogenic amine content. Because of the ability of producing biogenic amine of every bacteria was different, Valsamaki et al (2000) reported that it was not determined correlation between formed biogenic amine content and microorganism count.

Table 1 Microbiological Analyses Results of Cheese Samples (cfu/g)

\begin{tabular}{l|cccccc}
\hline \multirow{2}{*}{ Microorganisms } & \multicolumn{3}{|c}{ Erzincan Tulum Cheese } & \multicolumn{3}{c}{ Kars Kashar Cheese } \\
\cline { 2 - 7 } & Min. & Max. & Mean & Min. & Max. & Mean \\
\hline TAMB & $1.0 \times 10^{5}$ & $1.9 \times 10^{7}$ & $4.3 \times 10^{6} \pm 1.1 \times 10^{6}$ & $2.0 \times 10^{4}$ & $2.3 \times 10^{7}$ & $2.6 \times 10^{6} \pm 1.2 \times 10^{6}$ \\
LAB & $5 \times 10^{3}$ & $3.1 \times 10^{6}$ & $1.1 \times 10^{6} \pm 2.4 \times 10^{5}$ & $1.0 \times 10^{4}$ & $1.4 \times 10^{7}$ & $9.4 \times 10^{5} \pm 6.9 \times 10^{5}$ \\
FE & $<100$ & $4.0 \times 10^{2}$ & $1.1 \times 10^{2} \pm 1.5 \times 10$ & $<100$ & $<100$ & $<100$ \\
\hline
\end{tabular}

TAMB: Total Aerobic Mesophilic Bacteria; LAB: Lactic Acid Bacteria; FE: Fecal Enterobacteria 
Table 2 The chemical analyses results of cheese samples, $n=20$

\begin{tabular}{l|cc}
\hline \multirow{2}{*}{ Chemical properties } & Erzincan Tulum Cheese & Kars Kashar Cheese \\
\cline { 2 - 3 } & \multicolumn{1}{|c}{ Mean } & Mean \\
\hline Water activity, aw & $0.93 \pm 0.01$ & $0.94 \pm 0.00$ \\
Lactic acid, \% & $1.95 \pm 0.05$ & $1.43 \pm 0.07$ \\
pH value & $4.75 \pm 0.10$ & $5.20 \pm 0.02$ \\
Dry matter, \% & $55.95 \pm 0.71$ & $58.31 \pm 0.45$ \\
Protein, \% & $19.84 \pm 0.60$ & $26.06 \pm 0.28$ \\
Tyrosyne, mg/5g & $4.25 \pm 0.28$ & $3.34 \pm 0.26$ \\
TN, \% & $3.11 \pm 0.09$ & $4.09 \pm 0.04$ \\
WSN, \% & $0.86 \pm 0.03$ & $1.06 \pm 0.06$ \\
Ripening coefficient, \% & $28.13 \pm 1.28$ & $26.04 \pm 1.56$ \\
NPN, \% & $0.54 \pm 0.02$ & $0.74 \pm 0.04$ \\
PPN, \% & $0.32 \pm 0.02$ & $0.33 \pm 0.03$ \\
Fat, \% & $31.48 \pm 0.82$ & $25.74 \pm 0.48$ \\
Fat in dry matter, \% & $56.15 \pm 0.99$ & $44.17 \pm 0.86$ \\
Salt, \% & $2.32 \pm 0.18$ & $2.14 \pm 0.16$ \\
Salt in dry matter, \% & $4.13 \pm 0.30$ & $3.98 \pm 0.28$ \\
\hline
\end{tabular}

TN: Total Nitrogen; WSN: Watersoluble Nitrogen; NPN: Non-protein Nitrogen; PPN: Protease Peptone Nitrogen

Table 3 The biogenic amine levels of Tulum Cheese samples (mg/100g).

\begin{tabular}{l|cccc}
\hline \multicolumn{1}{c|}{ Biogenic Amines } & Determined sample number & Minimum & Maximum & Mean \\
\hline Tryptamine & 11 & 0.12 & 0.39 & $0.13 \pm 0.03$ \\
Phenylethylamine & 12 & 0.07 & 0.95 & $0.16 \pm 0.05$ \\
Putrecine & 15 & 0.06 & 2.21 & $0.51 \pm 0.13$ \\
Cadaverine & 17 & 0.02 & 2.13 & $0.45 \pm 0.15$ \\
Histamine & 13 & 0.08 & 0.32 & $0.12 \pm 0.02$ \\
Tyramine & 14 & 0.20 & 1.54 & $0.56 \pm 0.11$ \\
\hline Total & 19 & 0.02 & 6.58 & $1.93 \pm 0.37$ \\
\hline
\end{tabular}

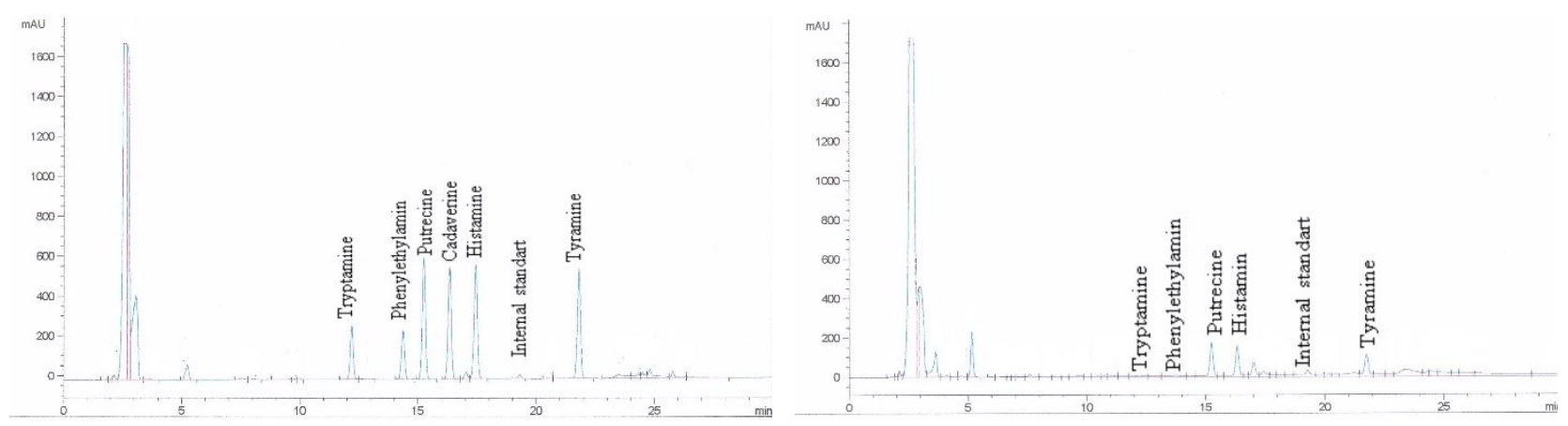

Figure 1 The standard chromatogram and Tulum cheese sample

There was a positive correlation between tryptamine and tyrosine which was a measuring of proteolysis $(\mathrm{r}=0.482 ; \mathrm{P}<0.05)$ (Table 4). It was admitted that the important factor for biogenic amine formation in cheese was presence of free amino acid as a substrate and amine formation at toxic levels depended on adequate free amino acid counts (Chang et al., 1985; Stratton et al., 1991; Antila et al., 1984; Joosten and Van-Boekel, 1988).The correlation between histamine and protein count was determined as $\mathrm{P}<0.05(\mathrm{r}=0.454)$. When protein amount increased, also biogenic amine formation increased, due to increasing of substrate count which was necessary for forming amine by microorganism (Chang et al., 1985; Stratton et al., 1991; Joosten and Van-Boekel, 1988). There was a negative correlation between phenylethylamine and ripening coefficient $(\mathrm{r}=-0.443 ; \mathrm{P}<0.05)$. In parallel with ripening progressive, it might be expected that biogenic amin counts increased under normal condition. However it can be seen different situation for biogenic amine formation. Similarly, it was determined that during the ripening while qualification of tyramine, cadaverine and putresine increased, the levels of other biogenic amines decreased in another research (Ordonez et al 1997).

Tyramine was the highest biogenic amine type in Kashar Cheese $(0.68 \pm 0.14 \mathrm{mg} / 100 \mathrm{~g})$ and it was followed by histamine, phenylethylamine, cadaverine, putrecine and tryptamine, respectively (Table 5). The presence of tryptamine, phenylethylamine, putrecine, cadaverine, histamine and tyramine were determined as $30,45,65,80$, 75 and $75 \%$, respectively. The total biogenic amine content of one sample was found as $1.62 \pm 0.26 \mathrm{mg} / 100 \mathrm{~g}$ in average. Kashar cheese sample and standard chromatograms are seen in Figure 2. 

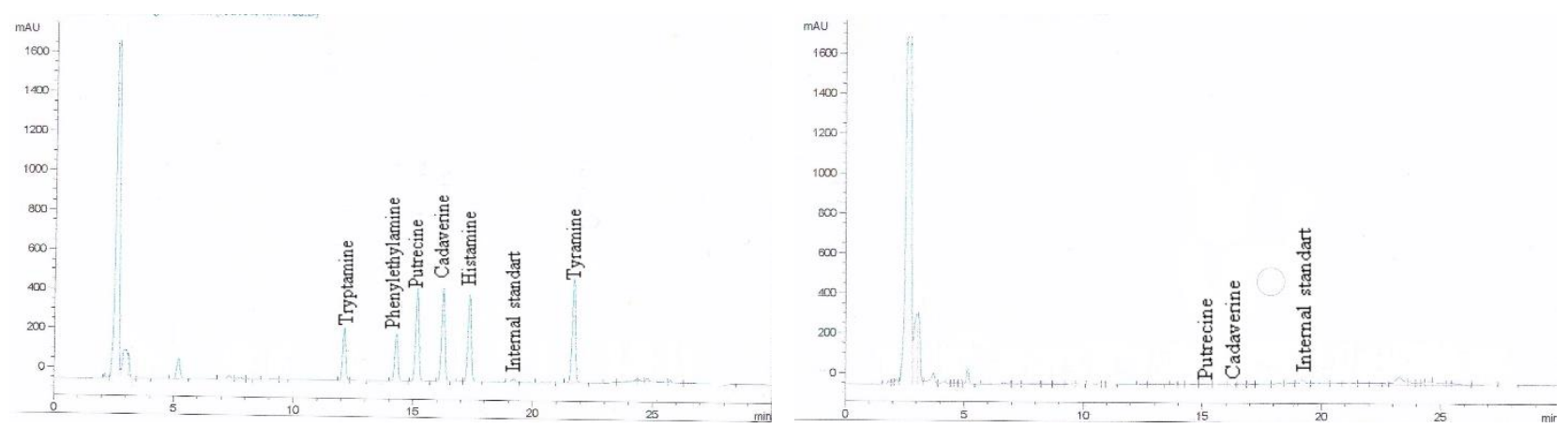

Figure 2 The standard chromatogram and Kashar cheese sample

Table 4 Correlation coefficient between biogenic amines and microbiological and physicochemical properties in Tulum cheese (r)

\begin{tabular}{l|rrrrrrr}
\hline \multicolumn{1}{c|}{ Chemical Properties } & \multicolumn{1}{c}{ TRY } & \multicolumn{1}{c}{ PHEN } & \multicolumn{1}{c}{ PUT } & \multicolumn{1}{c}{ CAD } & \multicolumn{1}{c}{ HIS } & \multicolumn{1}{c}{ TY } & \multicolumn{1}{c}{ TA } \\
\hline TMAB & -0.281 & -0.380 & -0.290 & -0.343 & -0.365 & -0.366 & -0.448 \\
LA & 0.193 & -0.369 & -0.180 & -0.408 & 0.289 & 0.091 & -0.214 \\
FE & -0.211 & -0.173 & -0.210 & -0.154 & -0.269 & -0.273 & -0.275 \\
Water activity, aw & 0.285 & 0.115 & 0.153 & 0.202 & 0.365 & 0.335 & 0.298 \\
Tyrosyne, mg/5g & $0.482^{*}$ & 0.068 & 0.163 & -0.033 & 0.152 & 0.123 & 0.142 \\
Lactic acid, \% & $0.472 *$ & -0.074 & 0.159 & -0.087 & 0.300 & 0.332 & 0.170 \\
pH value & 0.220 & -0.168 & 0.081 & -0.122 & 0.210 & 0.198 & 0.048 \\
Protein, \% & 0.381 & 0.238 & 0.126 & -0.007 & $0.454 *$ & 0.249 & 0.211 \\
TN, \% & 0.380 & 0.238 & 0.125 & -0.007 & $0.453 *$ & 0.249 & 0.210 \\
WSN, \% & 0.147 & -0.341 & 0.081 & -0.045 & 0.179 & 0.193 & 0.046 \\
Ripening coefficient, \% & -0.163 & $-0.443 *$ & -0.072 & -0.073 & -0.240 & -0.090 & -0.172 \\
NPN, \% & 0.180 & -0.326 & 0.000 & -0.138 & -0.101 & 0.028 & -0.082 \\
Salt, \% & -0.122 & 0.022 & 0.016 & 0.007 & -0.080 & -0.044 & -0.018 \\
Dry matter, \% & 0.092 & 0.358 & 0.204 & 0.029 & 0.201 & 0.220 & 0.217 \\
Fat, \% & 0.131 & 0.382 & 0.204 & 0.099 & 0.289 & 0.114 & 0.227 \\
\hline TRY: Tryptamine, PHEN: Phenyl-ethylamine, PUT: Putrecine
\end{tabular}

TRY: Tryptamine, PHEN: Phenyl-ethylamine, PUT: Putrecine, CAD: Cadaverine, HIS: Histamine, TY: Tyramine, TA: Total amine, TAMB: Total Aerobic Mesophilic Bacteria; LAB: Lactic Acid Bacteria; FE: Fecal Enterobacteria TN: Total Nitrogen; WSN: Watersoluble Nitrogen; NPN: Nonprotein Nitrogen; PPN: Protease Peptone Nitrogen, *: P<0.05

Table 5 The biogenic amine levels of Kashar Cheese samples (mg/100g)

\begin{tabular}{l|cccc}
\hline \multicolumn{1}{c|}{ Biogenic Amines } & Determined sample number & Minimum & Maximum & Mean \\
\hline Tryptamine & 6 & 0.08 & 0.36 & $0.07 \pm 0.03$ \\
Phenylethylamine & 9 & 0.07 & 1.35 & $0.22 \pm 0.09$ \\
Putrecine & 13 & 0.05 & 0.25 & $0.09 \pm 0.02$ \\
Cadaverine & 16 & 0.03 & 0.47 & $0.18 \pm 0.03$ \\
Histamine & 15 & 0.13 & 3.78 & $0.39 \pm 0.18$ \\
Tyramine & 15 & 0.31 & 2.41 & $0.68 \pm 0.14$ \\
\hline Total & 20 & 0.20 & 5.36 & $1.62 \pm 0.26$ \\
\hline
\end{tabular}

Table 6 Correlation coefficient between biogenic amines and microbiological and physicochemical properties in Kashar cheese (r)

\begin{tabular}{l|rrrrrrr}
\hline \multicolumn{1}{c|}{ Chemical Properties } & \multicolumn{1}{c}{ TRY } & PHEN & \multicolumn{1}{c}{ PUT } & \multicolumn{1}{c}{ CAD } & \multicolumn{1}{c}{ HIS } & \multicolumn{1}{c}{ TY } & \multicolumn{1}{c}{ TA } \\
\hline TMAB & 0.184 & -0.177 & 0.339 & -0.085 & -0.120 & -0.077 & -0.152 \\
LA & 0.265 & -0.088 & 0.345 & -0.105 & -0.076 & -0.005 & -0.046 \\
FE & - & - & - & - & - & - & - \\
Water activity, aw & 0.158 & 0.061 & 0.420 & -0.010 & -0.257 & -0.167 & -0.205 \\
Tyrosyne, mg/5g & $0.587 * *$ & 0.373 & $0.469^{*}$ & 0.408 & -0.031 & -0.167 & 0.152 \\
Lactic acid, \% & 0.316 & 0.368 & 0.319 & 0.132 & -0.195 & -0.272 & -0.091 \\
pH value & -0.357 & 0.076 & $-0.576^{* *}$ & -0.136 & 0.267 & 0.376 & 0.322 \\
Protein, \% & -0.085 & -0.360 & 0.008 & 0.120 & 0.089 & 0.157 & 0.034 \\
TN, \% & -0.054 & -0.369 & 0.032 & 0.146 & 0.084 & 0.145 & 0.028 \\
WSN, \% & 0.278 & 0.094 & 0.350 & 0.211 & 0.035 & -0.185 & 0.034 \\
Ripening coefficient, \% & 0.286 & 0.140 & 0.337 & 0.187 & 0.012 & -0.209 & 0.017 \\
NPN, \% & 0.343 & 0.099 & 0.437 & 0.209 & -0.020 & -0.187 & 0.008 \\
Salt, \% & 0.226 & 0.264 & -0.005 & 0.260 & -0.003 & 0.010 & 0.143 \\
Dry matter, \% & -0.075 & -0.079 & -0.296 & -0.185 & -0.034 & 0.120 & -0.036 \\
Fat, \% & -0.163 & 0.351 & -0.116 & -0.032 & -0.247 & -0.028 & -0.101 \\
\hline TRY: Try
\end{tabular}

TRY: Tryptamine, PHEN: Phenyl-ethylamine, PUT: Putrecine, CAD: Cadaverine, HIS: Histamine, TY: Tyramine, TA: Total amine, TAMB: Total Aerobic Mesophilic Bacteria; LAB: Lactic Acid Bacteria; FE: Fecal Enterobacteria TN: Total Nitrogen; WSN: Watersoluble Nitrogen; NPN: Non-protein Nitrogen; PPN: Protease Peptone Nitrogen, *: $\mathrm{P}<0.05 ; * *: \mathrm{P}<0.01$ 
According to the obtained results, the biogenic amine contents of Kars Kashar Cheese was not high and found below toxic doses (Halasz et al 1994).

The correlation coefficient between tryptamine and putresine with tyrosine was $\mathrm{r}=0.587(\mathrm{P}<0.01), \mathrm{r}=0.469$ $(\mathrm{P}<0.05)$, respectively (Table 6). As expected, when the tyrosine count increased, tryptamine and putresine counts increased. It was determined a remarkable negative correlation between putresine and $\mathrm{pH}$ value $(\mathrm{r}=-0.576)$ and this was important statistical $(\mathrm{P}<0.01)$. This situation was same as reported by Joosten (1988) and Chander et al (1989) that when $\mathrm{pH}$ value increased, formation of biogenic amine increased, on the contrary decreased.

\section{Acknowledgments}

This study was supported by BAP (Ankara Universty, Scientific Researches Projects) with the Project number of “20030711071”.

\section{References}

Alvarez MA, Moreno-Arribas MV. 2014. The problem of biogenic amines in fermented foods and the use of potential biogenic amine-degrading microorganisms as a solution. Trends in Food Science and Technol. 39: 146-155.

Anonymous. 2013. Beyaz Peynir. Türk Standartları Enstitüsü, 591, Ankara.

Antila P, Antila V, Mattila J, Makkarainen M. 1984. Biogenic amines in cheese. II. Factors influencing the formation of biogenic amines, with particular reference to the quality of the milk used in cheese making. Milchwissenschaft. 39 (7): 400404.

Bütikofer U, Fuchs D, Hurni D, Bosset JO. 1990. Beitrag zur bestimmung biogener amine in kase. Mitt. Gebiete Lebensm. Hgy. 81: 120-133.

Chander H, Batish VK, Babu S, Singh RS. 1989. Factors affecting amine production by a selective strain of Lactobacillus bulgaricus. Journal of Food Science. 54 (4): 940-942.

Chang SF, Ayres JW, Sandine WE. 1985. Analysis of cheese for histamine, tyramine, tryptamine, histidine, tyrosine and tryptophane. Journal of Dairy Science. 68: 2840-2846.

Çolak H, Hampikyan H, Bingol EB, Ulusoy B. 2007. Prevalence of L. monocytogenes and Salmonella spp. in Tulum cheese. Food Control. 18: 576-579

Dığrak M, Yılmaz Ö, Özçelik S. 1995. Elazığ kapalı çarşısında satışa sunulan Erzincan (Şavak) Tulum peynirlerinin mikrobiyolojik ve bazı fiziksel-kimyasal özellikleri. Gıda Dergisi 19 (6): 381-387.

Durlu-Özkaya F, Alichanidis E, Litopoulou-Tzanetaki E, Tunail N. 1999. Determination of biogenic amine content of Beyaz cheese and biogenic amine production ability of some lactic acid bacteria. Milchwissenschaft. 54 (12): 680-682.

Durlu-Özkaya F, Ayhan K, Özkan G. 2000. Biogenic amine determination in Tulum cheese by high performance liquid chromatography (HPLC). Milchwissenschaft. 55 (1): 27-28.

Durlu-Özkaya F, Tunail N. 2000. Salamura Beyaz Peynirlerde Biyogen Amin Riski. Süt Mikrobiyolojisi ve Katkı Maddeleri. VI. Süt ve Süt Ürünleri Sempozyumu Tebliğler Kitabı, Tekirdağ.

Durlu-Özkaya F. 2001. A comparative study on proteolytic activity, bacteriocin efficiency and biogenic amine formation of some Lactococcus, Enterococcus and Lactobacillus strains isolated from white pickled cheese. Ph.D. Thesis. Ankara University Graduate School of Natural and Applied Sciences, Dept. of Food Engineering, 134.
Durlu-Özkaya F. 2002. Biogenic amine content of some traditional Turkish cheeses. Biogenic Amines, Journal of Food Processing and Preservation. 26 (4): 259-265

Edwards ST, Sandine WE. 1981. Public health significancel of amines in cheese. Symposium; Microbial metabolites of importance in dairy products. Journal of Dairy Science. 64: 2431-2438.

Elsanhoty R, Mahrous H, Ghanaimy A. 2009. Chemical, microbiological counts and evaluation of biogenic amines during the ripening of Egyptian Soft Domiati cheese made from raw an pasteurized buffaloes milk. Int J Dairy Sci. 4: 80-90.

Eralp M. 1961. Peynir Teknolojisi. Ankara Üniversitesi Ziraat Fakültesi Yayınları: 172, Ankara.

Erdogan A, Gurses M, Sert S. 2003. Isolation of moulds capable of producing mycotoxins from blue mouldy Tulum cheeses produced in Turkey. International Journal of Food Microbiology. 85: 83-85.

Gripon JC, Desmazeaud MJ, Bars D, Bergere JL. 1975. Etude Du Role des Micro-Organismes et des Enzymes au Cours de la Maturatian des Fromages. Le Lait. 55 (548): 502-516.

Güven M, Konar A, Kleeberger A. 1995. İnek, koyun ve keçi sütlerinden üretilen ve deri tulumlarda farklı sürelerde olgunlaştırılan Tulum peynirlerinin bazı mikrobiyolojik özelliklerinin saptanması üzerinde karşılaştırmalı bir araştırma. Tr. Journal of Agriculture and Forestry. 19: 293-298.

Halasz A, Barath A, Simon-Sarkadi- Holzapfel W. 1994. Biogenic amines and their production by microorganisms in food. Trends in Food Science and Technology. 5: 42-49.

Halkman AK, Ayhan K. 2000. Gidaların mikrobiyolojik analizi 2. Mikroorganizma sayımı. Gida Mikrobiyolojisi ve Uygulamaları. Ankara Üniversitesi Ziraat Fakültesi Gıda Mühendisliği Bölümü Yayınları, Genişletilmiş 2. Baskı, 229254 s., Sim Matbaacilık, Ankara.

Harrigan WF, McCance ME. 1986. Laboratory methods in food and dairy microbiology. Academic Press, London.

Hayaloglu AA, Güven M, Fox PF. 2002. Microbiological, biochemical and technological properties of Turkish White cheese "'Beyaz peynir'. International Dairy Journal. 12: 635-648.

Hocalar B, Üren A. 2002. Çiğ sütten üretilen Beyaz peynirlerde biyojen aminler ve miktarları. Türkiye 7. Gida Kongresi. Ankara Üniversitesi Ziraat Fakültesi Gıda Mühendisliği Bölümü p.455-464.

Hull ME. 1947. Studies on milk proteins. II Colorimetric determination of the partial hydrolysis of the protein in milk. J. Dairy Sci. 30: 884.

ISO3433. 2008. Cheese-Determination of fat content-Van Gluik Method. The International Organization for Standardization.

ISO5534. 2004. Cheese and processed cheese- Determination of the Total Solid Content (Reference method). The International Organization for Standardization.

Joosten HMLJ. 1988. Conditions allowing the formation of biogenic amines in cheese. 3. Factors influencing the amounts formed. Neth. Milk Dairy Journal. 41: 329-345.

Joosten HMLJ, Stadhouders D. 1987. Conditions allowing the formation of biogenic amines in cheese. 1. Decarboxylative properties of starter bacteria. Neth. Milk. Dairy J. 41: 247-258.

Joosten HMLJ, Northolt MD. 1987. Conditions allowing the formation of biogenic amines in cheese. 2. Decarboxylative properties of some non-starter bacteria. Neth.Milk Dairy J. 41: 259-280.

Joosten HMLJ, Van-Boekel MAJS. 1988. Conditions allowing the formation of biogenic amines in cheese. 4. A study of the kinetics of histamine formation in an infected Gouda cheese. Neth. Milk Dairy Journal. 42: 3-24.

Joosten HMLJ, Gaya P, Nunez M. 1995. Isolation of tyrosine decarboxylaseless mutants of a bacteriocin producing Enterococcus faecalis strain and their application in cheese. Journal of Food Protection. 58 (11): 1222-1226. 
Karahan AG, Öner Z, Filiz HN. 2001. Farklı depolama sürelerinde Beyaz peynirlerde meydana gelen değişimler. Kromatografik Yöntemler, II. Ulusal Kromatografi Kongresi. p. 316-326.

Keleş A, Atasever M. 1996. Divle tulum peynirinin kimyasal, mikrobiyolojik ve duyusal kalite nitelikleri. Süt Teknolojisi. 1: 47-53.

Kıvanç M. 1989. Erzurum piyasasında tüketime sunulan Kaşar peynirlerinin mikrobiyel floras1. Gida Dergisi. 14 (1): 23-30.

Kurt A, Çamakçı S, Çağlar A, Akyüz N. 1991. Erzincan Tulum (Şavak) peynirinin yapılışı, duyusal, fiziksel ve kimyasal özellikleri üzerinde bir araştırma. Gıda Dergisi. 16 (5): 295 302.

Ladero V, Calles-Enriquez M, Fernandez M, Álvarez MA. 2010. Toxicological effects of dietary biogenic amines. Curr. Nutr. Food Sci. 6: 145-156.

Maijala R, Eerola S. 1993. Contaminant lactic acid bacteria of dry sausages produce histamine and tyramine. Meat Science. 35 (3): 387-395.

Marino M, Maifreni M, Moret S, Rondinini G. 2000. The capacity of Enterobacteriaceae species to produce biogenic amines in cheese. Letters in Applied Microbiology. 31: 169-173.

Ordonez AI, Ibanez FC, Torre P, Barcina Y. 1997. Formation of Biogenic Amines in Indiazal ewe's Milk Cheese: Effect of Ripening, pasteurization, and Starter. Journal Food Protect. 60 (11): 1371-1375.

Öksüz O, Kurultay Ş, Simşek O. 2001. The effect of Brevibacterium linens on some physico-chemical properties and colour intensity of Kashar cheese. Milchwissenschaft. 56: 82- 85 .

Öner Z, Şimşek B, Şen S. 2002. Piyasadan sağlanan İzmir ve Erzincan Tulum peynirlerinde belirlenen bazı kalite kriterleri. Türkiye 7. Gıda Kongresi. Ankara Üniversitesi Ziraat Fakültesi Gıda Mühendisliği Bölümü p. 334.

Renes E, Diezhandino I, Fernandez D, Ferrazza RE, Tornadijo ME, Fresno JM. 2014. Effect of autochthonous starter cultures on the biogenic amine content of ewe's milk cheese throughout ripening. Food Microbiology. 44: 271-277

Rosner B. 2006. Fundamentals of Biostatistics, 6 th ed., Thomson Higher Education 10 Davis Drive, Belmont, CA, USA.
Schirone M, Tofalo R, Fasoli G, Perpetuini G, Corsetti A, Manetta AC, Ciarrocchi A, Suzzi G. 2013. High content of biogenic amines in Percorino cheeses. Food Microbiology. 34: 137-144.

Sulejmani E, Hayaloglu AA, Rafajlovska V. 2014. Study of the chemical composition, proteolysis, volatile compounds, and textural properties of industrial and traditional Beaten (Bieno sirenje) ewe milk cheese. Journal of Dairy Science. 97: 12101224.

Sumner SS, Roche F. Taylor SL. 1990. Factors controlling histamine production in Swiss cheese inoculated with Lactobacillus buchneri. Journal of Dairy Science. 73: 30503058 .

Stratton JE, Hutkins RW, Taylor SL. 1991. Biogenic amines in cheese and other fermented foods: A review. Journal of Food Protection. 54 (6): 460-470.

Şenel E, Yıldız F, Yetişemiyen A, Durlu-Özkaya F, Öztekin FŞ, Şanlı E. 2012. Evaluation of the Biogenic amine content and some chemical and microbiological properties of Urfa and Van Herby cheeses. Kafkas Univ. Vet. Fak. Derg. 18 (4): $537-$ 544.

Taylor S, Keefe TJ, Windham ES. 1982. Outbreak of histamine poisoning associated with consumption of Swiss cheese. Journal of Food Protection. 45 (5): 455-457.

Tekinşen KK, Akar D. 2017. Erzincan Tulum Peyniri. Atatürk Üniversitesi Veteriner Bilimleri Dergisi. 12(2): 218-226.

Ünsal A. 1997. Süt Uyuyunca-Türkiye Peynirleri. I. Bask1, Yap1 Kredi Kültür Sanat Yayıncılık Ticaret ve Sanayi Anonim Şirketi, İstanbul.

Valsamaki K, Michaelidou A, Polychroniadou A. 2000. Biogenic amine production in Feta cheese. Food Chemistry. 71 (2): 299-266.

Yilmaz G, Ayar A, Akın N. (2005). The vect of microbial lipase on the lipolysis during the ripening of Tulum cheese. Journal of Food Engineering. 69: 269-274.

Yıldız F, Yetisemiyen A, Senel E, Durlu-Özkaya F, Öztekin, FS, Sanli E. 2010. Some Properties of Civil cheese: a type of traditional Turkish cheese. International Journal of Dairy Technology. 63 (4): 575-580. 